\title{
CREATING INNOVATIVE TOURISM EXPERIENCES THROUGH SUSTAINABLE VALORISATION OF ARCHAEOLOGICAL HERITAGE
}

\author{
Kristina Afrić Rakitovac \\ Nataša Urošević \\ Nikola Vojnović
}

https://doi.org/10.20867/tosee.05.28

\begin{abstract}
The paper presents the results of a research conducted within the framework of ArchaeoCulTour, a recent project whose main goal was to analyse the potential of valorising archaeological heritage in the Istria County, Croatia, through sustainable tourism. The main aim of the project is to develop a successful and innovative strategy for sustainable cultural tourism growth in Istria as the most developed Croatian tourist region, characterized by an abundance of archaeological sites, which are still not adequately valorised, presented and interpreted. The authors have tested the key hypotheses on a local case study - elaborating potentials for the valorisation of archaeological heritage in the Municipality of Vrsar in Western Istria, which was chosen because it represents a typical coastal tourist destination in Croatia and on the Mediterranean, characterized by mass tourism and a remarkable seasonality.

In this paper, the authors present the results of the third stage of the research - a tourist survey conducted during spring and summer 2018. The aim of the research was to analyse visitors's motivations and acitivites related to archaeological tourism in the Vrsar municipality and in the near-by Rovinj, which could be considered a model of sustainable cultural tourism development. The results have confimed the results of the previous two research phases, related to the experts' attitudes and the local community survey, both oriented towards considering the current tourism development trends in the observed municipality and its developement potentials. All key stakeholders agree that the main sustainability issues in the Vrsar municipality, i.e. high seasonality, mass tourism, infrastructure problems, could be resolved through sustainable valorisation of the local cultural and natural resources by creating innovative tourism expriences. Keywords sustainable tourism, archaeological heritage, innovative tourism, tourists' perception, Istria
\end{abstract}

\section{INTRODUCTION}

The turbulent global context, characterised by economic, social, environmental and political crises, requires the consideration of new models of management and the sustainable use of limited, valuable local resources. Global travel trends, marked by instability and dynamic changes, require an adjustment of the tourism offer to changing tourist demands. The current strategic policy frameworks at the European, national and regional levels define priorities as well in order to build a national and regional competitive advantage by the sustainable and innovative mobilisation of unique local resources in creating an integral destination product. 
ToSEE - Tourism in Southern and Eastern Europe, Vol. 5, pp. 1-15, 2019

K. Afrić Rakitovac, N. Urošević, N. Vojnović: CREATING INNOVATIVE TOURISM EXPERIENCES ...

Although the beginnings of tourism development in our region were characterized by some specific types of tourism (health and cultural tourism), which did not have a seasonal character, today Croatia is still positioned and recognized mostly as a summer destination. Such drastic seasonality, at the same time, represents a serious threat to the sustainability of the natural, cultural and social environment. On the other hand, while realizing almost a quarter of GDP from tourism, the country should ensure more sustainable ways of valorising its main capital and competitive advantage - the preserved natural and cultural heritage.

Extending the tourist season and transforming Croatia into a year-round destination are the main goals of the current Tourism Development Strategy of the Republic of Croatia. According to this strategic document, Croatia is a typical example of a mature tourist destination, dominated by one product ("the sun and the sea") with a highly seasonal business period, which is characteristic for warm countries by the sea, primarily in the Mediterranean and the Adriatic (Ministry of Tourism, 2013).

In such a context, certain specific forms of tourism, which already marked the history of Croatian tourism, could be analysed as a sustainable alternative to seasonal mass tourism and a positive generator of change. The proposed hypothesis is that sustainable cultural tourism, which 'cares for the culture it consumes while culturing the consumer' (Richards, 2007: 1), could strengthen the identity and economy of the local community, create new jobs, increase the quality of life of the local residents and visitors' enjoyment, improve the image of a place and extend the season.

The paper presents the results of a research conducted within the framework of ArchaeoCulTour, a recent project whose main goal was to analyse the potential of valorising archaeological heritage in the Istria County, Croatia, through sustainable tourism. The main aim of the project is to develop a successful and innovative strategy for sustainable cultural tourism growth in Istria as the most developed Croatian tourist region, characterized by an abundance of archaeological sites, which are still not adequately valorised, presented and interpreted. The authors have tested the key hypotheses on a local case study - elaborating potentials for the valorisation of archaeological heritage in the Municipality of Vrsar in Western Istria, which was chosen because it represents a typical coastal tourist destination in Croatia and on the Mediterranean, characterized by mass tourism and a remarkable seasonality.

Building on a comparative analysis of the European, as well as regional and national, best practice in the valorisation of this specific category of heritage, the authors proposed an innovative research methodology, which included a hybrid methodological approach, combining qualitative and quantitative methods involving all interested stakeholders (the local community, visitors, experts). The research included workshops involving all key stakeholders, whose main purpose was to define the current situation, the main problems, and development priorities. Interviews and focus groups with experts were supplemented by a local community survey and questionnaires for tourists, in which the attitudes towards the key attractions and development resources were explored, as well as the most appropriate models of sustainable tourism development. In this paper, the authors present the results of the third stage of the research - a tourist survey conducted during the summer of 2018. The aim of the research was to analyse visitors's motivations and 
ToSEE - Tourism in Southern and Eastern Europe, Vol. 5, pp. 1-15, 2019

K. Afrić Rakitovac, N. Urošević, N. Vojnović: CREATING INNOVATIVE TOURISM EXPERIENCES ...

acitivites related to archaeological tourism in the Vrsar municipality and in the near-by Rovinj, which could be considered a model of sustainable cultural tourism development.

\section{LITERATURE REVIEW}

Seasonality is one of the most important professional and scientific topics in the research of the tourism phenomenon. From the tourism scholars point of view, seasonality can be defined as a temporal imbalance in tourism, which may be expressed in terms of tourists' arrivals and overnights, visitors' and tourists' expenditures, traffic on roads, ports, airports and other forms of transportation, employment and admissions to attractions and tourist regions (Butler, 2001: 5). Seasonality is influenced by natural causes such as the climate, weather conditions, biological cycles (animal migrations) and sociocultural causes such as religious, social and political events, school and other holidays, lifestyles, and the pricing and promotion policies (Bar-On, 1999: 437).

The majority of tourist regions and countries, Croatia included, experience seasonal patterns of tourist activities (Baum and Lundtorp, 2001: 2; Jang, 2004: 819; Chung, 2009: 83; Kožić, 2013: 470). In the case of Croatia, seasonality is caused by the weather and climate conditions and the school holidays in the nearby emitting tourist regions of Central and Western Europe as the main market of Croatian tourism. Consequently, the summer season prevails in Croatia, meaning that $85 \%$ of tourist activities is based on the Sun and Sea Model (Croatian Government, 2013: 8) and strictly spatially concentrated on the narrow coastal strip and islands in the Adriatic seaside resorts of Istria, Kvarner and Dalmatia (Curić et al., 2012: 25; Vojnović, 2018: 31).

There are numerous Croatian and international publications which have offered scientific and professional suggestions, development models and potential solutions in order to reduce the negative implications of seasonality in the contemporary tourism demand (Jang, 2004: 819; Chung, 2009: 83; Čavlek et al., 2010: 139; Klarin, 2018: 44). Nevertheless, for the current scientific project and specific research, the most valuable are publications dealing with the Mediterranean seaside resorts similar to the Municipality of Vrsar and the western coast of the Istrian region, and research that considers the cultural, creative and archaeological tourism in the Mediterranean as development models and tools for reducing seasonality.

The authors assumed that sustainable cultural tourism, which 'cares for the culture it consumes while culturing the consumer' (Richards, 2007: 1), as a sustainable alternative to mass tourism, could strengthen the identity and economy of the local community, create new jobs, increase the quality of life of local residents and a visitor's enjoyment, improve the image of a place and extend the season.

Archaeotourism or archaeological tourism is an alternative type of cultural tourism that aims at promoting the passion for protection and valorisation of historical sites. It offers the traveller an unforgettable experience through intensive courses about these specialized manifestations of human knowledge. The passion for history and heritage can be manifested in tourism through offering the excavation of as yet undiscovered finds, which puts the traveller in a position to directly experience the practice of 
ToSEE - Tourism in Southern and Eastern Europe, Vol. 5, pp. 1-15, 2019

K. Afrić Rakitovac, N. Urošević, N. Vojnović: CREATING INNOVATIVE TOURISM EXPERIENCES ...

archaeology while learning a new skill. On the other hand, archaeological tourism also implies simply visiting archaeological sites, museums, interpretation centres, reenactments of historical events, festivals, theatres, and all those products connected with promoting archaeology to the public (Jelinčić, in: Mihalić, 2009: 27-28). Archaeological tourism resources include: sites on the World Heritage List, the protected urban entities and monuments, archaeological sites and archaeological landscapes, museums and archaeological parks, as well as different 'living history' events and manifestations.

In that sense, archaeological tourism can be seen as a form of creative tourism, i.e. tourism which offers visitors the opportunity to develop their creative potential through active participation in courses and learning experiences, which are characteristic of the holiday destination where they are taken (Raymond and Richards, 2000). As a complement to cultural tourism, creative tourism refers to travel directed towards an engaged and authentic experience, with participative learning in the arts, heritage, or special character of a place, and it provides a connection with those who reside in this place and create this living culture (UNESCO, 2006). These specific forms of cultural and creative tourism allow the diversification of the tourist offer without any investment, just by optimizing the existing tangible and intangible heritage. Besides supporting quality tourism endowed with a high added value and purchasing power, based on authenticity and sustainability of local culture, its deseasonalizing character allows a better distribution of the tourist activity along the year. The cultural, creative and archaeological tourism could bring more skilled, experienced and educated tourists, who are looking for more interactivity. Such visitors want to experience the local culture by participating in artistic and creative activities and combining many types of tourism during the same journey: creative, culinary, eco-tourism and slow tourism.

All these characteristics of the mentioned specific forms of tourism, which value and enrich the natural, cultural and human resources instead of exploiting them in an unsustainable way could help to resolve the mentioned key problems of tourism in Istria and Croatia, and in the other similar Mediterranean destinations: high seasonality and concentration on the coast, as well as an inadequate valorisation of the key local resources, including archaeological heritage.

However, cultural, heritage and archaeological tourism in the Mediterranean seaside and coastal destinations and regions are considered as development models and tools in reducing seasonality in a very few scientific papers. Among them, the most important and influential are papers on the Andalusia region in Spain (Cisneros- Martínez and Fernández-Morales, 2013) and Sicily in Italy (Cuccia and Rizzo, 2011). In the study of the seasonal concentration on the Andalusian coastline in the summer, the analysis was conducted by separating tourists according to their main travel motivation, and distinguishing the sun-and-sand tourists from the cultural and other segments of tourists, based on their place of origin and on the coast they decided to visit. Among the main results in Andalusia, given the heterogeneity of the groups of tourists, it was found that it was much more effective to separate the tourist segments by their main travel motivation. The cultural segment was the most favourable for deseasonalisation, especially among domestic tourists, while with foreigners the same deseasonalising effect was not present in all the coasts analysed. The study of the cultural destinations of Sicily focuses on cultural attractiveness of tourism destinations as a particular aspect of 
ToSEE - Tourism in Southern and Eastern Europe, Vol. 5, pp. 1-15, 2019

K. Afrić Rakitovac, N. Urošević, N. Vojnović: CREATING INNOVATIVE TOURISM EXPERIENCES ...

tourism supply, and aims to evaluate the role of cultural tourism in tourism seasonality. The seasonality and tourist presence in different destinations in Sicily is analysed according to destinations' various degrees of cultural attractiveness. The main results show that the contribution of cultural heritage in reducing tourism seasonality is rather limited in destinations close to the sea. On the other hand, seasonality is more limited in minor heritage sites.

In addition, there are very few domestic scientific studies and strategic documents on the interrelatedness between reducing seasonality and the cultural, heritage and archaeological tourism as specific forms of tourism in Croatia. Among those few are "Strategy for development of cultural tourism" (Tomljenović et al., 2003) and studies about the possibilities of cultural tourism development in Croatia (Tomljenović, 2006) and the Istrian region (Vojnović, 2015), on the tourism function of cultural heritage (Vrtiprah, 2006; Gredičak, 2008) and characteristics of the tangible cultural heritage valuation process in tourism (Matečić, 2016). A significant monograph on this topic is "Models of valorisation of cultural heritage in sustainable tourism" (Urošević and Afrić Rakitovac, 2017).

Furthermore, in this scientific research, it is important to review the literature on tourists' attitudes. Although scientific and professional publications on tourists' perceptions of tourism regions and country are relatively numerous, there is little literature on tourists' attitudes and perceptions regarding sustainability attributes in the cultural, heritage and archaeological tourism destinations. The most significant contributions on this topic were made by Poria et al. (2004), clarifying heritage tourism by identifying and segmenting the reasons for visiting heritage sites. Similarly, Poria et al. (2006 and 2013) explored the motivations of potential visitors to heritage sites and tourists' perceptions of the world heritage sites. Tourists' behaviour in heritage sites in the Campania Region was examined using a multidimensional analysis, and four types of non-resident cultural visitors have been identified by means of a clustering technique (De Simone, 2012).

Chung et al. (2015) examined the role of augmented reality applications for heritage site as part of smart tourism to provide information about destinations and attractions. This study presented theoretical and practical implications of using augmented reality applications in tourism.

Aydin and Alvarez's (2016) study aims to explore sustainability from a demand-based perspective and determine which attributes of the destination Cuzco, Peru were most frequently mentioned by tourists in their reviews. The findings indicated that tourists primarily evaluate a destination's sustainability in relation to those aspects that are more likely to affect their own experiences. In the most recent domestic study (Slunjski, 2018) the attitudes of tourists, excursionists and directors of tourist boards towards the potential valorisation of immovable cultural heritage in the Croatian inland region Međimurje is analysed in order to identify the most important cultural and heritage sites. The research has shown that tourists are not familiar enough with the cultural heritage of this region. The TOMAS survey of the Institute for Tourism (2018) examined travel motivation of tourists visiting Croatia, and their satisfaction with elements of tourism offer, including cultural attractions and events (which was the main topic of the TOMAS Cultural Tourism survey from 2008). 
ToSEE - Tourism in Southern and Eastern Europe, Vol. 5, pp. 1-15, 2019

K. Afrić Rakitovac, N. Urošević, N. Vojnović: CREATING INNOVATIVE TOURISM EXPERIENCES ...

Since the current analysis has indicated a lack of researches on tourists' attitudes and motivations regarding sustainability issues in the cultural, creative and archaeological tourism, the authors have developed a hybrid methodological approach, combining qualitative and quantitative methods and interviews with all interested stakeholders (the local community, visitors, experts). The research included workshops with all key stakeholders, whose main purpose was to define the current situation, the main problems and development priorities. Interviews and focus groups with experts were supplemented by a local community survey and questionnaires for tourists, in which the attitudes towards the key attractions and development resources were explored, as well as the most appropriate models for developing sustainable tourism.

\section{THE POTENTIALS OF VALORISING ARCHAEOLOGICAL LANDSCAPE IN VRSAR MUNICIPALITY - AN ANALYSIS OF TOURISTS' MOTIVATIONS AND PREFERENCES}

\subsection{Research methodology}

The aim of the empirical research was to analyse the attitudes of tourists in the Vrsar municipality regarding the different aspects of tourism development related with the aims of the scientific project "The Archaeological Landscape in Sustainable Development of Cultural Tourism in the Vrsar Municipality - ArchaeoCulTour". The research hypotheses were as follows: 1 . Specific forms of tourism, such as the cultural, creative and eco-tourism, diversify the tourism supply and extend the tourist season; 2. Sustainable valorization of archaeological heritage creates innovative tourist experiences in the Vrsar municipality.

A comparative analysis of the European and Croatian best practices regarding arhaeological tourism, as well as destination dynamics of the Istria County and the Vrsar municipality, are elaborated in previous research (Afrić Rakitovac, K; Urošević, N; Vojnović, N, 2018). The research was carried out in two phases, in May and July 2018, in the Vrsar municipality and in the near-by town of Rovinj, which could be considered a model of sustainable cultural tourism development. In Rovinj in May 2018 there were 73.797 arrivals and in July 201815.225 while in Vrsar there were 24.117 arrivals in May 2018 and in July 201852.030 (www.dzs.hr). The data were collected through a direct contact with tourists staying in different types of accommodation.

The research instrument was a questionnaire organised in five parts, consisting of 38 questions. The paper presents the selected questions and answers. The data have been analysed by methods of descriptive analysis and the One-way ANOVA analysis, processed with the SPSS programme 24.0. The characteristics of the sample are presented in following tables.

As indicated in Table 1, the structure of the sample according to gender is mostly balanced. 
ToSEE - Tourism in Southern and Eastern Europe, Vol. 5, pp. 1-15, 2019

K. Afrić Rakitovac, N. Urošević, N. Vojnović: CREATING INNOVATIVE TOURISM EXPERIENCES ...

Table 1: Sample structure by gender

\begin{tabular}{|l|r|r|r|r|r|r|r|r|}
\hline \multirow{2}{*}{ Gender } & \multicolumn{2}{|c|}{ Vrsar May } & \multicolumn{2}{c|}{ Rovinj May } & \multicolumn{2}{c|}{ Vrsar July } & \multicolumn{2}{c|}{ Rovinj July } \\
\cline { 2 - 9 } & \multicolumn{1}{c|}{$\mathbf{N}$} & \multicolumn{1}{c|}{ In \% } & \multicolumn{1}{c|}{ N } & \multicolumn{1}{c|}{ In \% } & \multicolumn{1}{c|}{ N } & \multicolumn{1}{c|}{ In \% } & \multicolumn{1}{c|}{ N } & \multicolumn{1}{c|}{ In \% } \\
\hline Male & 152 & 50.3 & 61 & 48.0 & 186 & 53.9 & 60 & 51,3 \\
\hline Female & 150 & 49.7 & 66 & 52.0 & 159 & 46.1 & 57 & 48,7 \\
\hline Total & $\mathbf{3 0 2}$ & $\mathbf{1 0 0 . 0}$ & $\mathbf{1 2 7}$ & $\mathbf{1 0 0 . 0}$ & $\mathbf{3 4 5}$ & $\mathbf{1 0 0 . 0}$ & $\mathbf{1 1 7}$ & $\mathbf{1 0 0 . 0}$ \\
\hline
\end{tabular}

Source: Authors' research

Regarding the age structure, the largest group were those in the age group from 30 to 39, followed by those from 40-49, with an exception in the Vrsar municipality having the largest group of tourists in May from the age group of 40-49, followed by those between 50-59 (Table 2).

Table 2: Sample structure by age

\begin{tabular}{|l|r|r|r|r|r|r|r|r|}
\hline \multirow{2}{*}{ Age } & \multicolumn{2}{|c|}{ Vrsar May } & \multicolumn{2}{c|}{ Rovinj May } & \multicolumn{2}{c|}{ Vrsar July } & \multicolumn{2}{c|}{ Rovinj July } \\
\cline { 2 - 10 } & \multicolumn{1}{|c|}{$\mathbf{N}$} & \multicolumn{1}{c|}{ In \% } & \multicolumn{1}{c|}{ N } & \multicolumn{1}{c|}{ In \% } & \multicolumn{1}{c|}{ N } & \multicolumn{1}{c|}{ In \% } & \multicolumn{1}{c|}{ N } & \multicolumn{1}{c|}{ In \% } \\
\hline $\mathbf{1 8 - 2 9}$ & 31 & 10.3 & 12 & 9.4 & 66 & 19.1 & 12 & 10.3 \\
\hline $\mathbf{3 0 - 3 9}$ & 48 & 15.9 & 38 & 29.9 & 117 & 33.9 & 41 & 35.0 \\
\hline $\mathbf{4 0 - 4 9}$ & 71 & 23.5 & 27 & 21.3 & 97 & 28.1 & 38 & 32.5 \\
\hline $\mathbf{5 0 - 5 9}$ & 66 & 21.9 & 19 & 15.0 & 42 & 12.2 & 19 & 16.2 \\
\hline $\mathbf{6 0}$ and more & 86 & 28.5 & 31 & 24.4 & 23 & 6.7 & 7 & 6.0 \\
\hline Total & 302 & 100.0 & 127 & 100.0 & 345 & 100.0 & 117 & 100.0 \\
\hline
\end{tabular}

Source: Authors' research

The structure of the sample regarding the level of education indicated the largest group of examinees with a university degree, followed by those with a secondary school degree. It is interesting to note that more than $60 \%$ of the tourists from the sample have at least a university degree (Table 3 )

Table 3: Sample structure by level of education

\begin{tabular}{|l|r|r|r|r|r|r|r|r|}
\hline \multirow{2}{*}{$\begin{array}{l}\text { Level of } \\
\text { education }\end{array}$} & \multicolumn{2}{|c|}{ Vrsar May } & \multicolumn{2}{c|}{ Rovinj May } & \multicolumn{2}{c|}{ Vrsar July } & \multicolumn{2}{c|}{ Rovinj July } \\
\cline { 2 - 9 } & $\mathbf{N}$ & \multicolumn{1}{c|}{ In \% } & \multicolumn{1}{c|}{ N } & \multicolumn{1}{c|}{ In $\%$} & \multicolumn{1}{c|}{ N } & \multicolumn{1}{c|}{ In \% } \\
\hline $\begin{array}{l}\text { Elementary } \\
\text { school }\end{array}$ & 20 & 6.6 & 8 & 6.3 & 10 & 2.9 & 3 & 2.6 \\
\hline $\begin{array}{l}\text { Secondary } \\
\text { school }\end{array}$ & 108 & 35.8 & 36 & 28.3 & 117 & 33.9 & 41 & 35.0 \\
\hline University & 131 & 43.4 & 60 & 47.2 & 162 & 47.0 & 50 & 42.7 \\
\hline $\begin{array}{l}\text { Master's } \\
\text { degree }\end{array}$ & 43 & 14.2 & 23 & 18.1 & 56 & 16.2 & 23 & 19.7 \\
\hline Total & 302 & 100.0 & 127 & 100.0 & 345 & 100.0 & 117 & 100.0 \\
\hline
\end{tabular}

Source: Authors' research

Regarding the actual position in the labour market, the majority of examinees are employed, followed by those who are entrepreneurs, retirees and students (Table 4). 
ToSEE - Tourism in Southern and Eastern Europe, Vol. 5, pp. 1-15, 2019

K. Afrić Rakitovac, N. Urošević, N. Vojnović: CREATING INNOVATIVE TOURISM EXPERIENCES ...

Table 4: Sample structure by the actual position in the labour market

\begin{tabular}{|c|c|c|c|c|c|c|c|c|}
\hline \multirow{2}{*}{$\begin{array}{l}\text { Actual } \\
\text { position in } \\
\text { the labour } \\
\text { market }\end{array}$} & \multicolumn{2}{|c|}{ Vrsar May } & \multicolumn{2}{|c|}{ Rovinj May } & \multicolumn{2}{|c|}{ Vrsar July } & \multicolumn{2}{|c|}{ Rovinj July } \\
\hline & $\mathbf{N}$ & In $\%$ & $\mathbf{N}$ & In $\%$ & $\mathbf{N}$ & In $\%$ & $\mathbf{N}$ & In $\%$ \\
\hline Employed & 160 & 53.0 & 66 & 52.0 & 230 & 66.7 & 65 & 55.6 \\
\hline Entrepreneur & 38 & 12.6 & 21 & 16.5 & 44 & 12.8 & 29 & 24.8 \\
\hline Student & 14 & 4.6 & 6 & 4.7 & 27 & 7.8 & 10 & 8.5 \\
\hline Retiree & 85 & 28.1 & 28 & 22.0 & 28 & 8.1 & 12 & 10.3 \\
\hline Unemployed & 5 & 1.7 & 6 & 4.7 & 16 & 4.6 & 1 & 0.9 \\
\hline Total & 302 & 100.0 & 127 & 100.0 & 345 & 100.0 & 117 & 100.0 \\
\hline
\end{tabular}

Source: Authors' research

Regarding the sample structure by the type of accommodation, most tourists interviewed in Vrsar were located in camps (more than $60 \%$ ), followed by those who chose hotels and tourist resorts. Those staying in Rovinj are mostly situated in hotels (more than a half), followed by camps (Table 5).

Table 5: Sample structure by the type of accommodation

\begin{tabular}{|l|r|r|r|r|r|r|r|r|}
\hline \multirow{2}{*}{ Options } & \multicolumn{2}{|c|}{ Vrsar May } & \multicolumn{2}{c|}{ Rovinj May } & \multicolumn{2}{c|}{ Vrsar July } & \multicolumn{2}{c|}{ Rovinj July } \\
\cline { 2 - 9 } & \multicolumn{1}{|c|}{ N } & \multicolumn{1}{c|}{ In \% } & \multicolumn{1}{c|}{ N } & \multicolumn{1}{c|}{ In \% } & \multicolumn{1}{c|}{ In } & \multicolumn{1}{c|}{ In } & \multicolumn{1}{|c|}{ In \% } \\
\hline Hotel & 75 & 24.8 & 65 & 51.2 & 56 & 16.2 & 64 & 54.7 \\
\hline Camp & 200 & 66.2 & 45 & 35.4 & 209 & 60.6 & 45 & 38.5 \\
\hline Tourist resort & 23 & 7.6 & 11 & 8.7 & 62 & 18.0 & 2 & 1.7 \\
\hline $\begin{array}{l}\text { Private } \\
\text { accommodation }\end{array}$ & 3 & 1.0 & 3 & 2.4 & 15 & 4.3 & 5 & 4.3 \\
\hline At friend's & 1 & .3 & 3 & 2.4 & 3 & 0.9 & 1 & 0.9 \\
\hline Total & 302 & 100.0 & 127 & 100.0 & 345 & 100.0 & 117 & 100.0 \\
\hline
\end{tabular}

Source: Authors' research

\subsection{Research results}

In the first group of questions, the tourists were asked to evaluate the significance of the proposed attractions in choosing either Vrsar or Rovinj for their holiday.

As indicated in Table 6, the most attractive factors for the tourists choosing Vrsar were the characteristics of the sea around Vrsar (arithmetic means on Likert's scale 4.59 and 4.37), followed by the weather and climate (4.51 and 4.29), the coast and isles (4.37 and 4.24). In the context of the purpose of the paper, the archaeological site Monte Ricco was expectedly the least important attraction factor $(3.28 ; 3.23)$. The results were further analysed using the One-way ANOVA analysis. It can be concluded that there are statistically significant differences in answers between tourists coming to Vrsar in May compared to those coming in Vrsar in July, in relation to the following elements of attractiveness: the characteristics of the sea, the weather and the climate, the coast and isles, the natural and cultural vegetation, the parks and landscaped public green areas, and Vrsar's old city centre. 
ToSEE - Tourism in Southern and Eastern Europe, Vol. 5, pp. 1-15, 2019

K. Afrić Rakitovac, N. Urošević, N. Vojnović: CREATING INNOVATIVE TOURISM EXPERIENCES ...

Table 6: Importance of proposed attractions for tourists coming to Vrsar in May and July 2018

\begin{tabular}{|c|c|c|c|}
\hline \multirow{2}{*}{ Attraction } & \multicolumn{2}{|c|}{ Arithmetic mean } & \multirow{2}{*}{$\mathbf{F}(\mathbf{p})$} \\
\hline & May 2018 & July 2018 & \\
\hline Characteristics of the sea around Vrsar & 4.59 & 4.37 & $14.349(0.000)$ \\
\hline The weather and the climate & 4.51 & 4.29 & $15.093(0.000)$ \\
\hline The coast and isles & 4.37 & 4.24 & $4.857(0.028)$ \\
\hline The natural and cultivated vegetation & 4.22 & 3.93 & $19.253(0.000)$ \\
\hline The Lim Bay & 3.94 & 3.80 & $3.533(0.061)$ \\
\hline Parks, landscaped public green areas & 4.03 & 3.86 & $6.052(0.014)$ \\
\hline The Kontija Forest & 3.66 & 3.52 & $2.943(0.087)$ \\
\hline $\begin{array}{l}\text { St. Michael's Monastery and Church in } \\
\text { Kloštar }\end{array}$ & 3.43 & 3.29 & $3.094(0.079)$ \\
\hline The archaeological site Monte Ricco & 3.28 & 3.23 & $0.411(0.522)$ \\
\hline Vrsar's mosaics (the old Neon) & 3.36 & 3.31 & $0.474(0.492)$ \\
\hline $\begin{array}{l}\text { The Church of St. Mary of the Sea and the } \\
\text { ruins of the monastery }\end{array}$ & 3.42 & 3.37 & $0.357(0.550)$ \\
\hline Vrsar's old city centre & 4.04 & 3.87 & $5.332(0.021)$ \\
\hline Dušan Džamonja's Park of Sculptures & 3.38 & 3.28 & $1.650(0.199)$ \\
\hline The culinary tradition & 3.87 & 3.81 & $0.565(0.452)$ \\
\hline Cultural, sports and entertainment events & 3.49 & 3.74 & $10.413(0.001)$ \\
\hline
\end{tabular}

Source: Authors' research

As indicated in Table 7, the most attractive factors for the tourists coming to Rovinj, a nearby city, were the characteristics of the sea around Rovinj (arithmetic means on Likert's scale 4.57 and 4.51$)$, followed by the weather and climate $(4.54 ; 4.51)$, the coast and isles $(4.51 ; 4.45)$. In the context of the purpose of the paper, the archaeological sites (Monkodonja) were expectedly the least important attraction factor $(3.51 ; 3.35)$. The results were further analysed using the One-way ANOVA analysis. It can be concluded that there are statistically significant differences in answers between the tourists visiting Vrsar in May compared to those coming to Rovinj in July, in relation to the following elements of attractiveness: natural and cultivated vegetation; parks, landscaped public green areas; the protected natural sites: Zlatni rt, Palud, the isles, and the cultural, sports and entertainment events.

Table 7: Importance of proposed attractions for tourists coming to Rovinj in May and July 2018

\begin{tabular}{|l|r|r|r|}
\hline \multirow{2}{*}{ Attraction } & \multicolumn{2}{|c|}{ Arithmetic mean } & \multirow{2}{*}{ F (p) } \\
\cline { 2 - 3 } & May 2018 & July 2018 & \\
\hline Characteristics of the sea around Rovinj & 4.57 & 4.51 & $0.371(0.543)$ \\
\hline The weather and the climate & 4.54 & 4.51 & $0.110(0.741)$ \\
\hline The coast & 4.51 & 4.45 & $0.409(0.523)$ \\
\hline The natural and cultivated vegetation & 4.13 & 3.79 & $\mathbf{7 . 4 3 4 ( 0 . 0 0 7 )}$ \\
\hline The Lim Bay & 3.69 & 3.46 & $3.081(0.080)$ \\
\hline Parks, landscaped public green areas & 4.00 & 3.73 & $\mathbf{5 . 1 7 0}(\mathbf{0 . 0 2 4})$ \\
\hline Protected nature: Zlatni rt, Palud, the isles & 4.02 & 3.52 & $\mathbf{1 6 . 5 8 6 ( 0 . 0 0 0 )}$ \\
\hline Rovinj's old city centre & 4.28 & 4.33 & $0.353(0.553)$ \\
\hline
\end{tabular}


ToSEE - Tourism in Southern and Eastern Europe, Vol. 5, pp. 1-15, 2019 K. Afrić Rakitovac, N. Urošević, N. Vojnović: CREATING INNOVATIVE TOURISM EXPERIENCES ...

\begin{tabular}{|l|r|r|r|}
\hline \multirow{2}{*}{ Attraction } & \multicolumn{2}{|c|}{ Arithmetic mean } & \multirow{2}{*}{ F (p) } \\
\cline { 2 - 3 } & May 2018 & July 2018 & \\
\hline Church monuments & 3.69 & 3.69 & $0.004(0.951)$ \\
\hline Archaeological sites (Monkodonja) & 3.51 & 3.35 & $1.711(0.192)$ \\
\hline The culinary tradition & 3.95 & 3.99 & $0.115(0.735)$ \\
\hline Cultural, sports and entertainment events & 3.74 & 3.41 & $\mathbf{7 . 1 3 7 ( 0 . 0 0 8 )}$ \\
\hline
\end{tabular}

Source: Authors' research

The following questions were related to the tourists' activities in the destination. As indicated in Table 8, the most frequent activity of tourists visiting Vrsar is related to swimming and other recreational activities in the sea and by the sea $(4.33 ; 4.54)$, followed by visiting restaurants and walking the landscaped walkways. The least frequent activities are related to participating in the local community's activities, visiting archaeological sites, attending cultural events and sightseeing. The results were further analysed using the One-way ANOVA analysis. It can be concluded that there are statistically significant differences in answers between the tourists coming to Vrsar in May compared to those coming in Vrsar in July, in relation to the following activities: visiting restaurants and attending cultural events.

Table 8: Tourists' activities in Vrsar, May and July 2018

\begin{tabular}{|l|r|r|r|}
\hline \multirow{2}{*}{ Attraction } & \multicolumn{2}{|c|}{ Arithmetic mean } & \multirow{2}{*}{ F (p) } \\
\cline { 2 - 3 } & May 2018 & \multicolumn{1}{|c|}{ July 2018 } & \\
\hline $\begin{array}{l}\text { Swimming and other recreational activities } \\
\text { in the sea and by the sea }\end{array}$ & 4.33 & 4.54 & $12.261(0.000)$ \\
\hline $\begin{array}{l}\text { Visiting and staying in protected natural } \\
\text { areas (the Lim Bay, Kontija) }\end{array}$ & 3.76 & 3.79 & $0.112(0.738)$ \\
\hline Cycling & 3.65 & 3.54 & $1.469(0.226)$ \\
\hline Visiting restaurants & 4.12 & 3.90 & $\mathbf{1 0 . 4 2 5 ( 0 . 0 0 1 )}$ \\
\hline Sightseeing & 3.37 & 3.50 & $2.862(0.091)$ \\
\hline Visiting archaeological sites & 3.36 & 3.21 & $2.285(0.131)$ \\
\hline Attending cultural events & 3.37 & 3.50 & $\mathbf{6 . 7 7 1 ( 0 . 0 0 9 )}$ \\
\hline Attending entertainment and sport events & 3.42 & 3.63 & $1.241(0.266)$ \\
\hline $\begin{array}{l}\text { Participating in the local community's } \\
\text { activities }\end{array}$ & 3.33 & 3.42 & $2.247(0.134)$ \\
\hline Walking the landscaped walkways & 4.02 & 3.92 & $2.850(0.092)$ \\
\hline New experiences and adventures & 3.94 & 3.82 & $3.033(0.082)$ \\
\hline
\end{tabular}

Source: Authors' research

As indicated in Table 9, the most frequent activity of tourists visiting Rovinj is related to swimming and other recreational activities in the sea and by the sea $(4,42 ; 4.39)$, followed by visiting restaurants and walking the landscaped walkways. The least frequent activities are related to participating in the local community's activities, attending cultural events and sightseeing. The results were further analysed using the One-way ANOVA analysis. It can be concluded that there are statistically significant differences in answers between the tourists coming to Rovinj in May compared to those coming in July, in relation to the following activities: attending entertainment and sports events, participating in the local community's activities, walking the landscaped walkways, visiting archaeological sites and attending cultural events. 
ToSEE - Tourism in Southern and Eastern Europe, Vol. 5, pp. 1-15, 2019

K. Afrić Rakitovac, N. Urošević, N. Vojnović: CREATING INNOVATIVE TOURISM EXPERIENCES ...

Table 9: Tourists' activities in Rovinj, May and July 2018

\begin{tabular}{|l|c|c|c|}
\hline Activity & \multicolumn{2}{|c|}{ Arithmetic mean } & F (p) \\
\hline $\begin{array}{l}\text { Swimming and other recreational activities } \\
\text { in the sea and by the sea }\end{array}$ & 4.42 & 4.39 & $0.069(0.793)$ \\
\hline $\begin{array}{l}\text { Visiting and staying in protected natural } \\
\text { areas (Lim Bay, Kontija) }\end{array}$ & 4.10 & 3.91 & $2.847(0.093)$ \\
\hline Cycling & 3.97 & 3.97 & $0.002(0.965)$ \\
\hline Visiting restaurants & 4.15 & 4.21 & $0.360(0.549)$ \\
\hline Sightseeing & 3.89 & 3.97 & $0.545(0.461)$ \\
\hline Attending cultural events & 3.65 & 3.68 & $0.035(0.852)$ \\
\hline Attending entertainment and sports events & 3.71 & 3.54 & $\mathbf{1 . 9 6 5 ( 0 . 0 0 2 )}$ \\
\hline $\begin{array}{l}\text { Participating in the local community's } \\
\text { activities }\end{array}$ & 3.65 & 3.40 & $\mathbf{4 . 4 4 8}(\mathbf{0 . 0 3 6})$ \\
\hline Walking the landscaped walkways & 4.19 & 3.86 & $\mathbf{9 . 9 4 2}(\mathbf{0 . 0 0 2})$ \\
\hline New experiences and adventures & 4.03 & 3.91 & $0.888(0.347)$ \\
\hline
\end{tabular}

Source: Authors' research

The next questions were related to the tourists' interests regarding archaeological heritage. When asked about their interest to explore the local archaeological heritage, it is interesting to note that more than a half of them express their interest (Table 10.

Table 10: Tourist's interest in exploring the local archaeological heritage

\begin{tabular}{|l|r|r|r|r|r|r|r|r|}
\hline \multirow{2}{*}{ Answers } & \multicolumn{2}{|c|}{ Vrsar May } & \multicolumn{2}{c|}{ Rovinj May } & \multicolumn{2}{c|}{ Vrsar July } & \multicolumn{2}{c|}{ Rovinj July } \\
\cline { 2 - 9 } & N & \multicolumn{1}{c|}{ In \% } & \multicolumn{1}{c|}{ N } & \multicolumn{1}{c|}{ In \% } & N & \multicolumn{1}{c|}{ In \% } & N & \multicolumn{1}{|c|}{ In \% } \\
\hline YES & 169 & $\mathbf{5 6 . 0}$ & 72 & $\mathbf{5 6 . 7}$ & 194 & $\mathbf{5 6 . 2}$ & 54 & $\mathbf{4 6 . 2}$ \\
\hline No & 133 & 44.0 & 55 & 43.3 & 151 & 43.8 & 63 & 53.8 \\
\hline Total & 302 & 100.0 & 127 & 100.0 & 345 & 100.0 & 117 & 100.0 \\
\hline
\end{tabular}

Source: Authors' research

In the next questions, the tourists which expressed their interest in exploring the local archaeological heritage were asked about a potential activity they would be interested in, and they were asked if they were willing to pay for it. As indicated in Table 11, for the tourists visiting Vrsar, the best way to do this is through cultural routes or archaeological parks, followed by events - living history programmes, interpretation centres and museums, and through interactive workshops. Approximately three-quarters of tourists are ready to pay for such a creative, innovative experience.

Table 11: Preferred ways of exploring archaeological heritage for tourists visiting Vrsar

\begin{tabular}{|c|c|c|c|c|c|c|}
\hline \multirow{3}{*}{ Activity } & \multicolumn{3}{|c|}{ May } & \multicolumn{3}{|c|}{ July } \\
\hline & \multirow{2}{*}{$\mathbf{N}$} & \multicolumn{2}{|c|}{ Willingness to pay } & \multirow{2}{*}{$\mathbf{N}$} & \multicolumn{2}{|c|}{ Willingness to pay } \\
\hline & & $\mathbf{N}$ & In \% & & $\mathbf{N}$ & In \% \\
\hline $\begin{array}{l}\text { Through interactive } \\
\text { workshops }\end{array}$ & 56 & 45 & 80.3 & 92 & 76 & 82.6 \\
\hline Archaeological parks & 86 & 66 & 76.7 & 123 & 96 & 78.0 \\
\hline Cultural routes & 97 & 59 & 60.8 & 117 & 84 & 71.7 \\
\hline
\end{tabular}


ToSEE - Tourism in Southern and Eastern Europe, Vol. 5, pp. 1-15, 2019 K. Afrić Rakitovac, N. Urošević, N. Vojnović: CREATING INNOVATIVE TOURISM EXPERIENCES ...

\begin{tabular}{|c|c|c|c|c|c|c|}
\hline \multirow{3}{*}{ Activity } & \multicolumn{3}{|c|}{ May } & \multicolumn{3}{|c|}{ July } \\
\hline & \multirow{2}{*}{$\mathbf{N}$} & \multicolumn{2}{|c|}{ Willingness to pay } & \multirow{2}{*}{$\mathbf{N}$} & \multicolumn{2}{|c|}{ Willingness to pay } \\
\hline & & $\mathbf{N}$ & In \% & & $\mathbf{N}$ & In \% \\
\hline $\begin{array}{l}\text { Interpretational } \\
\text { centres/museums }\end{array}$ & 70 & 54 & 77.1 & 101 & 80 & 79.2 \\
\hline $\begin{array}{l}\text { Events - living history } \\
\text { programmes }\end{array}$ & 76 & 47 & 61.8 & 101 & 72 & 71.3 \\
\hline
\end{tabular}

Source: Authors' research

As indicated in Table 12, for the tourists visiting Rovinj, the best way of exploring archaeological sites is through cultural routes or archaeological parks. As indicated in Table 12, for the tourists visiting Rovinj, the best way to do so is through cultural routes and archaeological parks, followed by interpretation centres and museums, events living history programmes, and through interactive workshops. Approximately $80 \%$ of tourists are ready to pay for such a service.

Table 12: Preferred ways of exploring archaeological heritage for tourists visiting Rovinj

\begin{tabular}{|c|c|c|c|c|c|c|}
\hline \multirow{3}{*}{ Activity } & \multicolumn{3}{|c|}{ May } & \multicolumn{3}{|c|}{ July } \\
\hline & \multirow{2}{*}{$\mathbf{N}$} & \multicolumn{2}{|c|}{ Willingness to pay } & \multirow{2}{*}{$\mathbf{N}$} & \multicolumn{2}{|c|}{ Willingness to pay } \\
\hline & & $\mathbf{N}$ & In \% & & $\mathbf{N}$ & In \% \\
\hline $\begin{array}{l}\text { Through interactive } \\
\text { workshops }\end{array}$ & 35 & 17 & 48.6 & 39 & 30 & 76.9 \\
\hline Archaeological parks & 46 & 32 & 69.5 & 43 & 33 & 76.7 \\
\hline Cultural routes & 46 & 39 & 84.7 & 46 & 35 & 76.1 \\
\hline $\begin{array}{l}\text { Interpretational } \\
\text { centres/museums }\end{array}$ & 42 & 29 & 69.0 & 38 & 32 & 84.2 \\
\hline $\begin{array}{l}\text { Events - living history } \\
\text { programmes }\end{array}$ & 41 & 21 & 51.2 & 35 & 29 & 82.9 \\
\hline
\end{tabular}

Source: Authors' research

In addition, the tourists were asked about their intention to visit a cultural attraction or event during their stay in Istria. As indicated in Table 13 approximately one third of them intend to visit a cultural attraction or event.

Table 13: Tourists' interest in visiting a cultural attraction or event

\begin{tabular}{|l|r|r|r|r|r|r|r|r|}
\hline \multirow{2}{*}{ Answers } & \multicolumn{2}{|c|}{ Vrsar May } & \multicolumn{2}{c|}{ Rovinj May } & \multicolumn{2}{c|}{ Vrsar July } & \multicolumn{2}{c|}{ Rovinj July } \\
\cline { 2 - 9 } & \multicolumn{1}{c|}{ N } & \multicolumn{1}{c|}{ In \% } & \multicolumn{1}{c|}{ N } & \multicolumn{1}{c|}{ In \% } & \multicolumn{1}{c|}{ N } & \multicolumn{1}{c|}{ In \% } & \multicolumn{1}{c|}{ N } & \multicolumn{1}{|c|}{ In \% } \\
\hline YES & 135 & 44.7 & 49 & 38.6 & 126 & 36.5 & 39 & 33.3 \\
\hline NO & 187 & 55.3 & 78 & 61.4 & 219 & 63.5 & 78 & 66.7 \\
\hline TOTAL & 302 & 100.0 & 127 & 100.0 & 345 & 100.0 & 117 & 100.0 \\
\hline
\end{tabular}

Source: Authors' research

The last question was related only to tourists staying in Rovinj. When asked about their interest to explore the cultural and archaeological heritage in near-by towns like Vrsar, more than a half expressed their interest to do so (Table 14). 
ToSEE - Tourism in Southern and Eastern Europe, Vol. 5, pp. 1-15, 2019

K. Afrić Rakitovac, N. Urošević, N. Vojnović: CREATING INNOVATIVE TOURISM EXPERIENCES ...

Table 14: Tourists' interest to explore the cultural and archaeological heritage in near-by towns like Vrsar

\begin{tabular}{|l|rr|r|r|r|}
\hline \multirow{2}{*}{ Answer } & \multicolumn{3}{|c|}{ Rovinj May } & \multicolumn{2}{c|}{ Rovinj July } \\
\cline { 2 - 5 } & $\mathbf{N}$ & In \% & N & \multicolumn{1}{c|}{ In \% } \\
\hline YES & 66 & 52.0 & 61 & 52.1 \\
\hline NO & 61 & 48.0 & 56 & 47.9 \\
\hline TOTAL & 127 & 100.0 & 117 & 100.0 \\
\hline
\end{tabular}

Source: Authors' research

The research results are comparable with the TOMAS 2017 survey (2018) of the Institute for Tourism, in which "rest and recreation - passive recreation" (54.9\%) was the dominant motivation for travelling to Croatia. On the other hand, it is obvious that our respondents' preferences are to enjoy the preserved nature, regardless of the season: although the authors assumed that the tourists who visit Vrsar/Rovinj in May could be 'cultural tourists', their motivation and preferences are very similar to the tourists' arriving in July. Although tourists are mostly interested in rest, recreation and enjoyment in nature (which could be connected to ecotourism), when asked if they were interested in exploring the local archaeological heritage, more than a half of them answered positively. For the majority of respondents, the best way of exploring archaeological sites is through cultural routes or archaeological parks, followed by events - living history programmes, interpretation centres and museums, and through interactive workshops. Approximately three-quarters of tourists are ready to pay for such a service.

\section{CONCLUSION}

The research has confirmed that the tourists visiting Vrsar and Rovinj are mostly motivated by a possibility to rest and recreate in the preserved nature. Although only a third of them could be defined as 'cultural tourists' - since they planned a visit to cultural attraction/manifestation during their stay, more than a half of them are interested to attend organized activities related to the local archaeological heritage, mostly through cultural routes and archaeological parks and, even more importantly, most of them are willing to pay for such an experience. This means that tourists are not well informed about the local cultural heritage and the possibilities of experiencing it through innovative products of creative and archaeological tourism. The obtained results confirm the potentials of proper valorisation of archaeological heritage through sustainable tourism in order to create innovative tourism experiences as a way of extending the tourist season in the observed tourism destination. The research hypotheses, i.e. that specific forms of tourism, such as the cultural, creative and eco-tourism, diversify the tourism supply and extend the tourist season; and that the sustainable valorisation of archaeological heritage creates innovative tourist experiences in the Vrsar municipality, have been partially confirmed.

The results presented in this paper have confimed the results of the previous two research phases, related to the experts' attitudes and the local community survey, both oriented towards considering the current tourism development trends in the observed municipality and its developement potentials. All key stakeholders agree that the main sustainability 
ToSEE - Tourism in Southern and Eastern Europe, Vol. 5, pp. 1-15, 2019

K. Afrić Rakitovac, N. Urošević, N. Vojnović: CREATING INNOVATIVE TOURISM EXPERIENCES ...

issues in the Vrsar municipality, i.e. high seasonality, mass tourism, infrastructure problems, could be resolved through sustainable valorisation of the local cultural and natural resources by creating innovative tourism expriences.

\section{ACKNOWLEDGEMENT}

This work has been supported in part by Croatian Science Foundation under the project PAR-2017-02-1.

\section{REFERENCES}

Afrić Rakitovac, K., Urošević, N., Vojnović (2018), "Project ArchaeoCulTour: Innovative Valorization of Archaeological Heritage in Istria County Through Sustainable Cultural and Creative Tourism", in: V. Katsoni and M. Segarra-Oña (eds.), Smart Tourism as a Driver for Culture and Sustainability, Springer Proceedings in Business and Economics, pp. 61-77.

Aydin, B. and Alvarez, M.D. (2016), "English-speaking tourists' evaluation of sustainability attributes in cultural tourism destinations: The case of Cusco", Teorija in Praksa, Vol. 53, No. 4, pp. 942-958.

Bar-On, R. R. (1999), “The Measurement of Seasonality and its Economic Impacts”, Tourism Economics, Vol. 5, No. 4, pp. 437-458. doi:10.1177/135481669900500409

Baum, T. and Lundtorp, S. (2001), "Seasonality in Tourism: An Introduction", Baum, T. and Lundtorp, S. (eds.), Seasonality in tourism, Pergamon, London and Amsterdam, pp. 1-4.

Buršić-Matijašić, K., Matijašić, R. (2017), "Management of Archaeological Heritage in Istria County", in: Afrić Rakitovac, Urošević (eds.), Models of Valorisation of Cultural Heritage in Sustainable Tourism, Pula.

Butler, R.W. (2001), "Seasonality in Tourism: Issues and Implications", Baum, T. and Lundtorp, S. (eds.), Seasonality in tourism, Pergamon, London and Amsterdam, pp. 5-21.

Chung, J.Y. (2009), "Seasonality in tourism: A review", e-Review of Tourism Research (eRTR), Vol. 7, No. 5 , pp. 82-96

Chung, N., Han, H., Joun, Y. (2015), "Tourists' intention to visit a destination: The role of augmented reality (AR) application for a heritage site", Computers in Human Behavior, Vol. 50, pp. 588-599. doi.org/10.1016/j.chb.2015.02.068

Cisneros-Martínez, J.D. and Antonio Fernández-Morales, A. (2013), "Cultural tourism as tourist segment for reducing seasonality in a coastal area: the case study of Andalusia”, Current Issues in Tourism, Vol 18, No. 8, pp. 1-20. doi: 10.1080/13683500.2013.861810

Croatian Government (2013), Tourism Development Strategy of Croatia by 2020, Zagreb.

Cuccia, T. and Rizzo, I. (2011), "Tourism seasonality in cultural destinations: Empirical evidence from Sicily", Tourism Management, Vol. 32, No. 3, pp.589-595. doi: 10.1016/j.tourman.2010.05.008

Curić Z., Glamuzina N., Opačić V.T. (2012), "Contemporary Issues in the Regional Development of Tourism in Croatia”, Hrvatski geografski glasnik, Vol. 74, No. 1, pp. 19-40. doi.org/10.21861/HGG.2012.74.01.02

Čavlek, N., Bartoluci, M., Kesar, O., Čižmar, S., Hendija, Z. (2010), "Contribution to Croatia's new tourism policy framework", Acta turistica, Vol 22., No 2, pp. 131-252.

De Simone, E. (2012), Non-residents' attitudes towards heritage: exploring tourist typologies by cultural consumption, Acta turistica, Vol. 24, No. 2, pp.177-208

Gredičak, T. (2008), "The tourism function of cultural heritage", Acta turistica nova, Vol. 2, No. 2, pp. 205 234.

Institut for Tourism (2018), TOMAS 2017: stavovi i potrošnja turista u Hrvatskoj, Institut za turizam, Zagreb. Jang, S. (2004), "Mitigating tourism seasonality A Quantitative approach", Annals of Tourism Research, Vol. 31, No. 4, pp. 819-836. doi: 10.1016/j.annals.2004.02.007

Klarin, T. (2018), "Assumptions for a successful implementation of the concept of sustainable tourism development: example of urban destinations of the Republic of Croatia", Acta turistica, Vol. 30, No. 1, pp. 43-85. doi: doi.org/10.22598/at/2018.30.1.43

Kožić, I. (2013), “The seasonality in tourism in Croatia”, Ekonomski vjesnik, Vol. XXVI, No. 2. pp. 470-480. 
ToSEE - Tourism in Southern and Eastern Europe, Vol. 5, pp. 1-15, 2019

K. Afrić Rakitovac, N. Urošević, N. Vojnović: CREATING INNOVATIVE TOURISM EXPERIENCES ...

Matečić, I. (2016), "Characteristics of the tangible cultural heritage valuation process in tourism", Acta Turistica, Vol. 28, No. 1, pp. 73-100.

Mihelić, S. (2009), Archaeology and Tourism in Croatia, Archaeological Museum Zagreb, Zagreb.

McKercher, B. i du Cros, H. (2002), Cultural Tourism, The Partnership Between Tourism and Cultural Heritage Management, The Haworth Press, Inc., Binghamton.

Poria, Y., Butler, R., Airey, D. (2004), "Links between Tourists, Heritage, and Reasons for Visiting Heritage Sites “, Journal of Travel Research, Vol. 43, No. 1, 19-28. doi.org/10.1177/0047287504265508

Poria, Y., Raichel, A., Biran, A. (2006), "Heritage Site Perceptions and Motivations to Visit", Journal of Travel Research, Vol. 44, No. 3, pp. 318-326 doi: 10.1177/0047287505279004

Poria, Y., Raichel, A., Cohen, R., (2013), "Tourists perceptions of World Heritage Site and its designation ", Tourism mangement, Vol. 35, pp. 272-274. doi.org/10.1016/j.tourman.2012.02.011

Richards, G. and Raymond, C. (2000, “Creative Tourism”, ATLAS News 23: 18.

Richards, G. (eds) (2007), Cultural Tourism. Global and Local Perspectives, The Haworth Press, New York.

Slunjski, R. (2018), "Tourism valorisation of immovable tangible cultural heritage in Medimurje", Hrvatski geografski glasnik, Vol. 80, No. 2, pp. 111-137. doi 10.21861/HGG.2018.80.02.05

Tomljenović, R., Marušić, Z., Weber, S., Hendija Z. and Boranić, S. (2003), Strategija razvoja kulturnog turizma - Od turizma i kulture do kulturnog turizma, Institut za turizam, Zagreb.

Tomljenović, R. (2006), “Kulturni turizam”, in: Čorak S. and Mikačić V. (eds.), Hrvatski turizam: plavo bijelo zeleno, Institut za turizam, Zagreb, pp. 119-147.

Urošević, N. and Afrić Rakitovac, K. (Eds.), (2017), Models of valorisation of cultural heritage in sustainable tourism, , Juraj Dobrila University of Pula, Pula.

Vojnović, N. (2015), "Potentials of the cultural heritage of Istria for the development of cultural tourism", in: Gržinić, J. and Vodeb, K. (Eds.), Cultural tourism and destination impacts, Juraj Dobrila University of Pula, Pula, pp. 229-258

Vojnović, N. (2018), “Tourist intensity in Croatia's leading tourist towns and municipalities”, Geoadria, Vol. 23, No. 1, pp. 29-50. doi.org/10.15291/geoadria.1453

Vrtiprah, V. (2006), "Cultural resources as a tourist supply factor in the 21st century", Ekonomska misao $i$ www.dzs.hr praksa, Vol. 15, No. 2, pp. 279-296.

Kristina Afrić Rakitovac, $\mathrm{PhD}$, Associate Professor

Juraj Dobrila University of Pula

Faculty of Economics and Tourism "Dr. Mijo Mirković"

Preradovićeva 1, 52100 Pula, Croatia

Phone: +385-52-377030

E-mail: kafric@unipu.hr

Nataša Urošević, $\mathrm{PhD}$, Assistant Professor

Juraj Dobrila University of Pula

Faculty of Interdisciplinary, Italian and Cultural Studies

Preradovićeva 1, 52100 Pula, Croatia

Phone: +385-52-377058

E-mail: nurosev@unipu.hr

Nikola Vojnović, PhD, Assistant Professor

Juraj Dobrila University of Pula

Faculty of Interdisciplinary, Italian and Cultural Studies

Preradovićeva 1, 52100 Pula, Croatia

Phone: +385-52-377040

E-mail: nvojnov@unipu.hr 